\title{
HISTORICAL DISSERTATIONS DEFENDED IN 2008
}

Vilma Akmenyte (Vytautas Magnus University, Lithuanian Institute of History) Latviu, Lietuvos-Latvijos pasienio gyventoju, tapatumo raida 1918-1940 m. [Identity Development of the Latvians Residing in the Lithuanian-Latvian Border Region in 1918-1940]

This study is aimed at analyzing the development of the identity of the residents of the Lithuanian-Latvian border area, taking into consideration the relation between the nation and the state, nationality and civic sense in those territories.

To examine the said issue the dissertation surveys the process of shaping the Latvian national minority in Kaunas and at the border of the former Courland Gubernia; it analyses the establishment of the Lithuanian-Latvian border in 1920-1921; it discusses the manifestation of the state power at the Lithuanian-Latvian border in 1918-1940 (the laws regulating granting of nationality, terms for crossing the state border, the regulations and specificities of economic activities of the border residents); and examines manifestations of the national identity of the Latvians residing at the Lithuanian-Latvian border in the period in question.

The thesis gives a strong focus on the aspects of the border, communication, education and language which are discussed with the aid of 'power' and 'market' concepts. It gives the author an opportunity to reconstruct the dynamics in the position of the border residents regarding the high politics and social changes. Church structures are not left aside since the Latvian minority in Lithuania belonged to different confessions and consequently developed unique models of national identity.

Marytė Černelienė (Vytautas Magnus University, Lithuanian Institute of History), Lenkijos lietuviu švietimas po Antrojo pasaulinio karo [The Education of the Lithuanian Minority in Poland after the Second World War]

The aim of the dissertation is to examine opportunities for arranging the education of the Lithuanian minority in Poland and working in that direction by indicating the key factors shaping and affecting the position 
and specific character of the Lithuanian minority in Poland, revealing the views held by the state and local authorities, security structures and Lithuanian organizations regarding the problems of education of the Lithuanians.

The chronological framework of the study is the period 1944-2008. In addition to the introduction and conclusions, the dissertation consists of three sections. The first analyses both the general policies of Poland regarding national minorities and the situation of the Lithuanians in Poland as well as the opportunities of their community to function in that context. The second section discusses the education policy for national minorities in Poland, schools which have Lithuanian classes, the education reforms of the late twentieth century, activities of Lithuanians from Seinai and Punskas in the field of education, etc. The third section is based on data from questionnaires used by the author for conducting a survey in 2006 which disclose how the Lithuanian schools and their teachers had been affected by the ideological propaganda in the Communist Poland.

Vilius Ivanauskas (Klaipėda University, Lithuanian Institute of History), Lietuviškoji nomenklatūra biurokratineje sistemoje: tarp stagnacijos ir dinamikos (1970-1988 m.) [Lithuanian Nomenclature in the Bureaucratic System: Between Stagnation and Dynamics (1970-1988)]

This study analyses the 'backstage' setting of the Soviet authorities in Lithuania during the period of 'real socialism'. It defines the relationship between the Lithuanian nomenclature and the Soviet system as well as identifies relevant issues in the complexity of the local nomenclature. By describing the internal relations, obligations and interests of the nomenclature in categories of social networking, the author considers the Lithuanian nomenclature as a separate social formation exceeding the boundaries of the formal nomenclature-based system.

The author distinguishes, describes, and analyses three major groups: party functionaries, technocrats and cultural functionaries. Although they were very different, the entire Lithuanian nomenclature in the Soviet period was characterized by a model of internal relations which supported the influence and power of local party functionaries ('partocrats'). This model enabled the development of a specific bureaucratic culture and provided better opportunities to promote social economic progress and avoid the centre's initiatives intended to limit the autonomy of the republic. A 
significant focus in the dissertation is laid on the subject of 'regionalism'. The author refers to that phenomenon as the project of partocrats and the rational strategy of the leaders of the republic which by means of symbolic manifestations was influencing the 'national' spirit of the public.

Ingrida Jakubavičienė (Vilnius University), Lietuvos vokiečiu nacionalsocialistinè veikla (XX a. 3-4 dešimtmečiuose) [National-Socialist Activities of the Lithuanian Germans in the 1920s-1930s]

The aim of the study is both to analyse the national-socialist activities of the Germans in Lithuania in the period in question and to examine the reaction of the Lithuanian authorities to the activities of the said organizations. It is also intended to assess their relationship with the Lithuanian authorities as well as the impact of such relationship on the mutual cooperation between Lithuania and Germany.

The study is structured so as to reveal the most important cases of national-socialist activities by Germans in Lithuania. The first section covering the period of 1920-1932 deals with the activities of the main parties of the Lithuanian Germans and their ties with Germany, emphasizing the special role played by the General Consulate of Germany and the German Embassy in Kaunas. The second section covers the period of 1933-1937 and scrutinizes a particularly active phase: establishment of Nazi organizations, fight for their leadership, the influence of the National Socialist German Workers' Party on the activities of the said organizations and the efforts of the Lithuanian authorities to block the anti-state work of the national-socialists. The third section analyses the events of Klaipeda Region from the mid-1938 to 1939 strongly focusing on the analysis of activities of the Kulturverband (cultural organization) of Klaipeda Region. The research has shown that the ties of the Germans of Klaipeda Region with the Nazi groups in Germany began in the 1920s. Throughout the period in question every effort was made for the activities of the organizations of the Germans in Lithuania to be coordinated by the agents sent from the centres of the NSDAP in Germany or the German Embassy in Lithuania so as to subject the former local organizations for implementation of the state-importance interests of Germany. 
Valdas Selenis (Vytautas Magnus University, Lithuanian Institute of History), Lietuvos istoriku bendrija 1918-1940 metais [The Community of Historians in Lithuania, 1918-1940]

Selenis examines the community of historians in independent Lithuania and the early stages of how history became a profession in Lithuania. The aim is to analyse the composition of the historian community of the period in question and specific features of professionalism: special education, circumstances of post-graduate studies, impact of social aspects of the collective biography on professionalism of the historian community, ideological views and competition as well as professional career, i.e. work, activities and membership in history science institutions.

The study consists of an introduction, six chapters and conclusions. The first chapter defines the historian community. The second and third sections analyse their education, preparation and maintaining of theses. Chapter four deals with the social aspects, i.e. territorial and social origin of historians, their ethnic and confessional background etc. Chapter five reveals ideological principles prevailing in the community of scholars in question. The professional structure of the historian community is disclosed in the sixth section.

The addenda contain a list and brief biographies of the historians.

Daiva Simanavičiūtė (Vytautas Magnus University, Lithuanian Institute of History), Pasaulio lietuviu bendruomenès raida XX a. 5-8 dešimtmečiuose [Development of the World Lithuanian Community in the 1940s-1970s]

Simanavičiūtè aims to reconstruct the organizational and political aspects in the development of the World Lithuanian Community (WLC) in the given period.

The dissertation consists of four parts (in addition to the introduction, conclusions, bibliography and addenda). The first section surveys the migration policy of the First Lithuanian Republic solving the issues of uniting the Lithuanians scattered over the world. The second part focuses on the policy of the Western countries dealing with an issue of political refugees after the Second World War and reconstructs the early stage of the WLC development, characteristics of its formation and problems arising among representatives of different emigration waves. The third part describes processes and specific features of establishment of Lithuanian communities in different countries. The fourth section reconstructs and analyses the activities of the WLC in solving the issues of representation and political 
organization of the Lithuanian émigrés. This section also introduces the position of the WLC regarding ties with Lithuania, dynamics of political activities of the organization and a particular focus is laid on the political influence in the United States and the world in general.

Linas Venclauskas (Vytautas Magnus University, Lithuanian Institute of History), Moderniojo lietuviško antisemitizmo geneze ir raida (18831940 m.) [The Genesis and Development of Modern Lithuanian AntiSemitism (1883-1940)]

On the basis of periodicals from the period in question the dissertation seeks to identify with what epithets, images and stereotypes the Lithuanian Jewish community was presented to the readers, how those descriptive phrases were changing in the given period; to find out whether the ideological orientation of the press influenced the shaping of anti-Semitic discourse; to analyse what major differences and similarities regarding the 'Jewish Question' existed in different ideological groups; to disclose what characteristics of Jews were pointed out to the readers; to reveal the key figures of the modern Lithuanian anti-Semitic discourse and the phraseology which determined them.

The first section analyses the anti-Semitic information of Aušra, Šviesa, Varpas and Tèvynés sargas newspapers (1883-1918), strongly focusing on the anti-Semitism of such prominent figures as Motiejus Valančius and Vincas Kudirka. The author emphasizes that the periodicals which belonged to entirely opposite ideological groups absolutely agreed on the issue of Jews and were seeing the Jewish community as problematic. In the second part the author notes the already changed relationship between the communities in the inter-war years, despite the negative and reserved representation of the relations between Lithuanians and Jews in the public sphere.

Hektoras Vitkus (Klaipeda University, Lithuanian Institute of History), Holokausto atminties raida Lietuvoje [The Process of the Memory of the Holocaust in Lithuania]

This study deals with factors conditioning the process of remembering the Holocaust in Lithuania which are scrutinized from different analytical angles: the concepts allowing us to reveal the specific features in the development of Holocaust memory in Lithuania; inter-disciplinary methodological 
interpretations of the problems in formation of Holocaust memory; views of social groups, the state and power structures affecting the process of Holocaust memory in Lithuania.

The first section analyses different historiographic notions of the process of Holocaust memory. The second part focuses on an analysis of the concept functioning in theoretical cultural discourse of historical memory, which contributes to a better understanding of specific features in the development of Holocaust memory in Lithuania. The third section distinguishes and analyses the following phases: 1941-1944; the Soviet phase (ideological and propagandist mechanisms and their reflections in the culture are discussed separately), and the post-Soviet phase (the author isolates two questions, namely the changes in the reception of Holocaust memory in Independent Lithuania and typical features of the formation and functioning of the system of Holocaust memory sites).

Translated by Lina Guobiene 